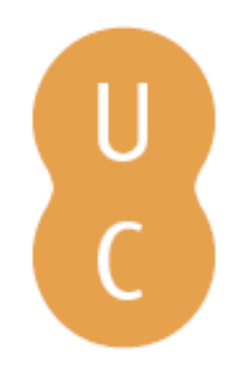

\title{
nommalina
}

\section{The fires of Mount Hymettus near Athens Greece (1996-2017): history and fire behavior characteristics}

Autor(es): $\quad$ Xanthopoulos, Gavriil; Athanasiou, Miltiadis

Publicado por: Imprensa da Universidade de Coimbra

URL

persistente: URI:http://hdl.handle.net/10316.2/44590

DOI: $\quad$ DOI:https://doi.org/10.14195/978-989-26-16-506_73

Accessed : $\quad$ 26-Apr-2023 14:13:24

A navegação consulta e descarregamento dos títulos inseridos nas Bibliotecas Digitais UC Digitalis, UC Pombalina e UC Impactum, pressupõem a aceitação plena e sem reservas dos Termos e Condições de Uso destas Bibliotecas Digitais, disponíveis em https://digitalis.uc.pt/pt-pt/termos.

Conforme exposto nos referidos Termos e Condições de Uso, o descarregamento de títulos de acesso restrito requer uma licença válida de autorização devendo o utilizador aceder ao(s) documento(s) a partir de um endereço de IP da instituição detentora da supramencionada licença.

Ao utilizador é apenas permitido o descarregamento para uso pessoal, pelo que o emprego do(s) título(s) descarregado(s) para outro fim, designadamente comercial, carece de autorização do respetivo autor ou editor da obra.

Na medida em que todas as obras da UC Digitalis se encontram protegidas pelo Código do Direito de Autor e Direitos Conexos e demais legislação aplicável, toda a cópia, parcial ou total, deste documento, nos casos em que é legalmente admitida, deverá conter ou fazer-se acompanhar por este aviso.

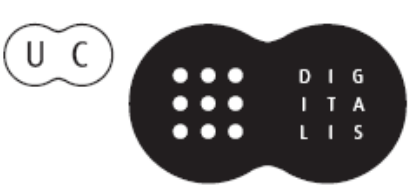




\section{ADVANCES IN}

\section{FOREST FIRE RESEARCH}

\section{8}

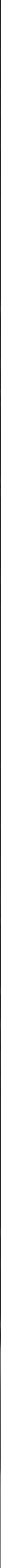




\title{
The fires of Mount Hymettus near Athens Greece (1996-2017): history and fire behavior characteristics
}

\author{
Gavriil Xanthopoulos ${ }^{1 *}$; Miltiadis Athanasiou ${ }^{2}$ \\ ${ }^{1}$ Hellenic Agricultural Organization "Demeter”, Institute of Mediterranean Forest Ecosystems. \\ Terma Alkmanos, Ilisia, 11528, Athens, Greece, \{gxnrtc@fria.gr*\} \\ ${ }^{2}$ Wildfire Management Consulting and Training. 8 Thoma Paleologou st., \\ Acharnes 13673, Athens, Greece, \{info@m-athanasiou.gr\}
}

\begin{abstract}
Mount Hymettus is a mountain lining the east side of Athens, the capital of Greece. Its proximity to the city, its flammable vegetation, and the variety of human activities (recreation, beekeeping, etc.) often result in problems with forest fires, which have reached a very high frequency in the last twenty years. These fires are of significant interest to firefighters, civil protection officers, foresters and the public because of their causes, their spread characteristics and associated safety risks, and their effects.

In the present paper, a brief account of the forest fires on Mt Hymettus in the 1996-2017 period is presented. Emphasis is put on the observed fire behavior which can be of interest to modeling studies of topographic influence on fire spread, and, since two of these fires have led to fatalities, may be used as case study illustrating a combination of fire environment conditions that entails great risk to firefighters. It is concluded that special care is needed regarding fire prevention and firefighting regarding fire management on Mount Hymettus. Professional and volunteer firefighters need to receive training that highlights the increased risks that fires on this mountain present. Furthermore, as the number of visitors is very high, special attention must be devoted to them, regarding both fire prevention and risk avoidance.
\end{abstract}

Keywords: Forest fire, chimney effect, canyon, fire fatality, Mount Hymettus, Greece

\section{Introduction}

Mount Hymettus is a mountain lining the east side of Athens, the capital of Greece. Its proximity to the city, its flammable vegetation, and the variety of human activities (recreation, beekeeping, etc.) often result in problems with forest fires, which have reached a very high frequency in the last twenty years or so. These fires are of significant interest to firefighters, civil protection officers, foresters and the public because of their causes, their spread characteristics and associated safety risks, and their effects.

Among Attica mountains, Mt Hymettus has been described as a "a remnant of the land that then was" in the Socratic dialogue Timaeus and Critias where the phenomenon of the erosion is described as "considerable accumulation of the soil coming down from the mountains, as in other places, but the earth has fallen away all round and sunk out of sight. The consequence is, that in comparison of what then was, there are remaining only the bones of the wasted body, as they may be called, as in the case of small islands, all the richer and softer parts of the soil having fallen away, and the mere skeleton of the land being left.". Furthermore, it can be deduced that the vegetation types covering many areas were mostly phrygana, since "mountains now only afford sustenance to bees".

Since antiquity, Mount Hymettus has been revegetated and then denuded many times, sometimes through fire but mostly through overgrazing and excessive vegetation cutting for fuelwood. At the time of the construction of the all-marble Panathenian stadium at its foothills facing Athens, for the first Modern Olympic Games in 1896, it was shown devoid of tall vegetation in all photos of that period. At the end of the World War II, tree vegetation on the mountain had again been removed 
completely because it had been used for the needs of the people of Athens. The protection the mountain received after that, and a series of reforestation efforts, led to the development of a patchy forest. This forest however, has suffered many fires in the last three decades.

In the present paper, a brief account of the forest fires on Mt Hymettus in the 1996-2017 period is presented. Emphasis is put on the observed fire behavior which can be of interest to modeling studies of topographic influence on fire spread, and, since two of these fires have led to fatalities, may be used as case study illustrating a combination of fire environment conditions that entails great risk to firefighters.

\section{Mount Hymettus and its environment as related to forest fires}

Mount Hymettus runs in a NE to SW direction defining the eastern edge of the city of Athens. It reaches a maximum elevation of $1026 \mathrm{~m}$, has a maximum length of $20 \mathrm{~km}$ and width of $6 \mathrm{~km}$, forming a perimeter of $65 \mathrm{~km}$ with a total area of $81 \mathrm{sq}$. km. Its vegetation consists of Meditereranean pine forest, Pinus halepensis and planted Pinus brutia, Mediterranean evergreen shrubs such as Quercus coccifera, Pistacia lentiscus, Genista acanthoclada, etc., and phrygana such as Cistus creticus, Cistus parviflorus, Sarcopoterium spinosum, etc. It is a Site of Community Importance (SCI) according to 92/43/EEC European Commission Habitats Directive (code GR3000006). As it belongs to the European Union's Natura 2000 network of sites, it enjoys a special environmental protection status.

Precipitation is relatively low, ranging around $400 \mathrm{~mm}$ per year. July and August, are usually completely dry. The prevailing wind during the fire season, from June to early September, is from the NE, blowing along the general direction of the mountain. This wind, known as "etisies" from the ancient Greek times, blows in the summer in all the Aegean sea, mainly from June to September, and usually runs for three to four consecutive days reaching 7 and sometimes 8 Beaufort scale force (roughly $50-70 \mathrm{~km} / \mathrm{h}$ ) in a steady direction. It is also called "meltemi" wind.

On the west side of the mountain, which faces the city and where most fires occur, the slope is perpendicular to the direction of the wind. Fire spread is in the direction of the resultant of the wind and slope vectors. This means spread in a $\mathrm{S}$ to $\mathrm{SW}$ direction with a tendency to move upslope. Further to that, and especially interesting regarding firefighter safety, is that the slopes of Mount Hymettus, especially on its western side, are characterized by a series of steep canyons.

\section{Forest fire history (1996-2017)}

In the 1996 to 2017 period at least eleven significant fires occurred on Mount Hymettus (Figure 1). They were quite large for the size of the mountain and parts of them often stopped at the fridge of the city where there was no vegetation to burn. All of them required heavy aerial support for their suppression. These larger fires are summarized in Table 1. Many other smaller fires that take place every summer are suppressed quickly through initial ground attack and help from the air.

Table 1 - Some of the most important fires of the 1996-2017 period on Mount Hymettus

\begin{tabular}{|c|l|}
\hline Wildfire & \multicolumn{1}{|c|}{ Description and Fire Behaviour } \\
\hline $\begin{array}{c}\text { July 22, } \\
\mathbf{1 9 9 8}\end{array}$ & $\begin{array}{l}\text { Wind driven through a dense and tall pine forest, explosive in a canyon at the east flank } \\
\text { close to its heel where four fatalities occurred. } \mathrm{T}=35^{\circ} \mathrm{C}, \mathrm{RH}=25 \% \text {, North wind of } 30 \\
\mathrm{~km} / \mathrm{h} \text {, gusting to } 48 \mathrm{~km} / \mathrm{h} \text {. }\end{array}$ \\
\hline $\begin{array}{c}\text { August 4, } \\
\mathbf{2 0 0 3}\end{array}$ & $\begin{array}{l}\text { Medium to low intensity surface fire in relatively sparse vegetation, that had burned in } \\
1995, \text { near the municipality of Argiroupoli }\end{array}$ \\
\hline
\end{tabular}

Advances in Forest Fire Research 2018 - Page 662 


\begin{tabular}{|c|c|}
\hline $\begin{array}{l}\text { July 9, } \\
2005\end{array}$ & $\begin{array}{l}\text { Mostly surface fire that re-burned the same canyon where the four fatalities of July } 22 \text {, } \\
1998 \text { took place. The fire moved explosively within the canyon but the intensity was } \\
\text { medium due to reduced biomass. T }=31^{\circ} \mathrm{C}, \mathrm{RH}=54 \% \text {, WSW wind of } 7 \mathrm{~km} / \mathrm{h}\end{array}$ \\
\hline $\begin{array}{l}\text { July 30, } \\
2005\end{array}$ & $\begin{array}{l}\text { Wind driven, mostly surface fire of medium intensity due to relatively sparse fuel. It } \\
\text { was suppressed quickly through strong aerial attack. }\end{array}$ \\
\hline $\begin{array}{l}\text { July 16, } \\
2007\end{array}$ & $\begin{array}{l}\text { Active wind driven crown fire spreading through a dense and tall pine forest, including } \\
\text { spotting. } \mathrm{T}=30^{\circ} \mathrm{C}, \mathrm{RH}=35 \% \text {, North wind of } 30 \mathrm{~km} / \mathrm{h} \text {. Rate of spread at the head reached } \\
2.4 \mathrm{~km} / \mathrm{h} \text {. It was controlled by strong aerial resources. }\end{array}$ \\
\hline $\begin{array}{c}\text { August } \\
25,2007\end{array}$ & $\begin{array}{l}\text { Wind driven, high intensity and fast-spreading, mostly surface fire. Started around } \\
\text { noon, fanned by a strong north wind. It started between the houses of the municipality } \\
\text { of Papagos-Cholargos and the Mount Hymettus ring road. It was controlled before dusk } \\
\text { with the intervention of strong aerial resources and the help of the ring road that } \\
\text { stopped the upslope spread of the eastern flank. }\end{array}$ \\
\hline $\begin{array}{c}\text { June } 25, \\
2008\end{array}$ & $\begin{array}{l}\text { Mostly topography and wind driven crown fire, that started at the area of Glyka Nera } \\
\text { (NE side of the mountain). It run through a dense and tall pine forest, spreading upslope } \\
\text { and westwards, until it reached the top. It was controlled on the lee side. } \mathrm{T}=38^{\circ} \mathrm{C} \text {, } \\
\text { RH }=31 \% \text {, North wind of } 25 \mathrm{~km} / \mathrm{h}\end{array}$ \\
\hline $\begin{array}{l}\text { July 16, } \\
2008\end{array}$ & $\begin{array}{l}\text { Medium intensity surface and passive crown fire in a park of the municipality of } \\
\text { Kaisariani, below the ring road. Started around noon and was controlled a few hours } \\
\text { later with the help of aerial resources. }\end{array}$ \\
\hline $\begin{array}{c}\text { June } 15, \\
2009\end{array}$ & $\begin{array}{l}\text { A fire that started at 15:25 in the area of Ano Glyfada and was stopped by dusk at the } \\
\text { border of a settlement in the municipality of Voula. It exhibited high intensity and } \\
\text { became a crown fire when it burned up-canyon. }\end{array}$ \\
\hline $\begin{array}{c}\text { July 17, } \\
2015\end{array}$ & $\begin{array}{l}\text { A high intensity crown and surface fire. It burned southwards fanned by a strong } \\
\text { northern "meltemi" wind, reaching a maximum forward rate of spread of } 2 \mathrm{~km} / \mathrm{h} \text {. } \\
\text { Additionally, it backed into the perpendicular to the direction of the wind canyons, at } \\
\text { an explosive maximum up-canyon rate of spread of } 9 \mathrm{~km} / \mathrm{h} \text {. }\end{array}$ \\
\hline $\begin{array}{l}\text { August } \\
10,2017\end{array}$ & $\begin{array}{l}\text { A medium intensity surface fire between the municipalities of Kaisariani and Byron, } \\
\text { in relatively sparse vegetation that started around 14:00 and was controlled within two } \\
\text { hours with the help of aerial resources. }\end{array}$ \\
\hline
\end{tabular}




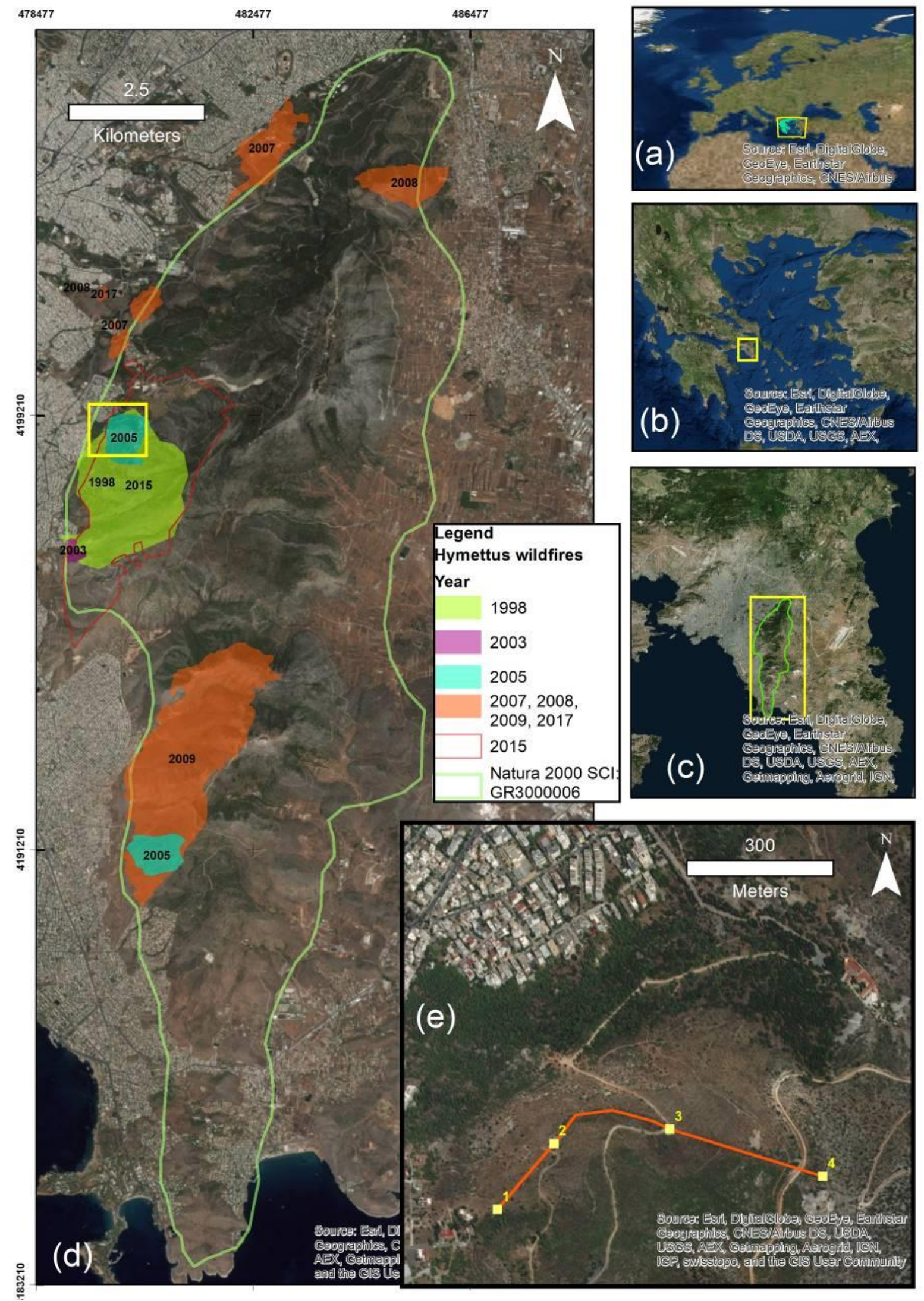

Figure 1 - The most important fires on Mount Hymettus in the 1996-2007 period. The geodetic system of the map and figure, is the Hellenic Geodetic Reference System 1987 
As the fires are clearly visible by the population of Athens, there are numerous reports, photos, opinions and comments in the Mass Media and on the Internet regarding these events. In most of these reports, the fires are attributed indiscriminately to "arsonists" who want to illegally occupy and develop forest land on Mount Hymettus. The majority of the public subscribe to this scenario or attribute the fire to political motives. In reality, there is no evidence leading to such conclusions. On the contrary, the small number of cases solved so far, include an immigrant burning old furniture (22 July 1998), a professional gun technician practicing shooting for testing ammunition (15 June 2009), a poor unemployed person with psychological problems who started multiple fires $(3,5,14$ and 22 July 2012), and two beekeepers who inadvertently started a fire while tending to their beehives using smoke (17 July 2015).

The large number of fires on Mount Hymettus and the significant damages they cause, have mobilized many people who live in the area to join volunteer groups, organized in each of the municipalities that border the mountain, offering their time for its protection. Regarding forest fires, these groups, in the summer, patrol the mountain, man lookout towers, and are immediately dispatched for initial attack when a fire is detected. Their positioning on the mountain is a major advantage because the traffic jams that Fire Service firetrucks face when coming from the Athens using the city's ring-road at the base of Mount Hymettus, often cause significant delays. On the other hand, the volunteers, having only light firetrucks, sometimes cannot cope with intense fast spreading fires.

\section{Forest fire behavior}

The majority of fires on Mount Hymettus have occurred from mid June to mid August. They usually start on days with strong wind at the base of the mountain at the fridge of the city. Fire spread under the strong wind is fast. Most importantly, as the fires run in a SW direction passing in front of the downslope "mouth" of the canyons, they are drawn-in, in a clear demonstration of the so-called "chimney effect". Fire spread within the canyon is very fast due to flame attachment (Sharples et al. 2010) and convection caused preheating of fuels mainly along its axis. As these canyons are protected to a large extent from the general wind, when there is significant amount of fuel, a strong convection column usually develops (Figure 2).

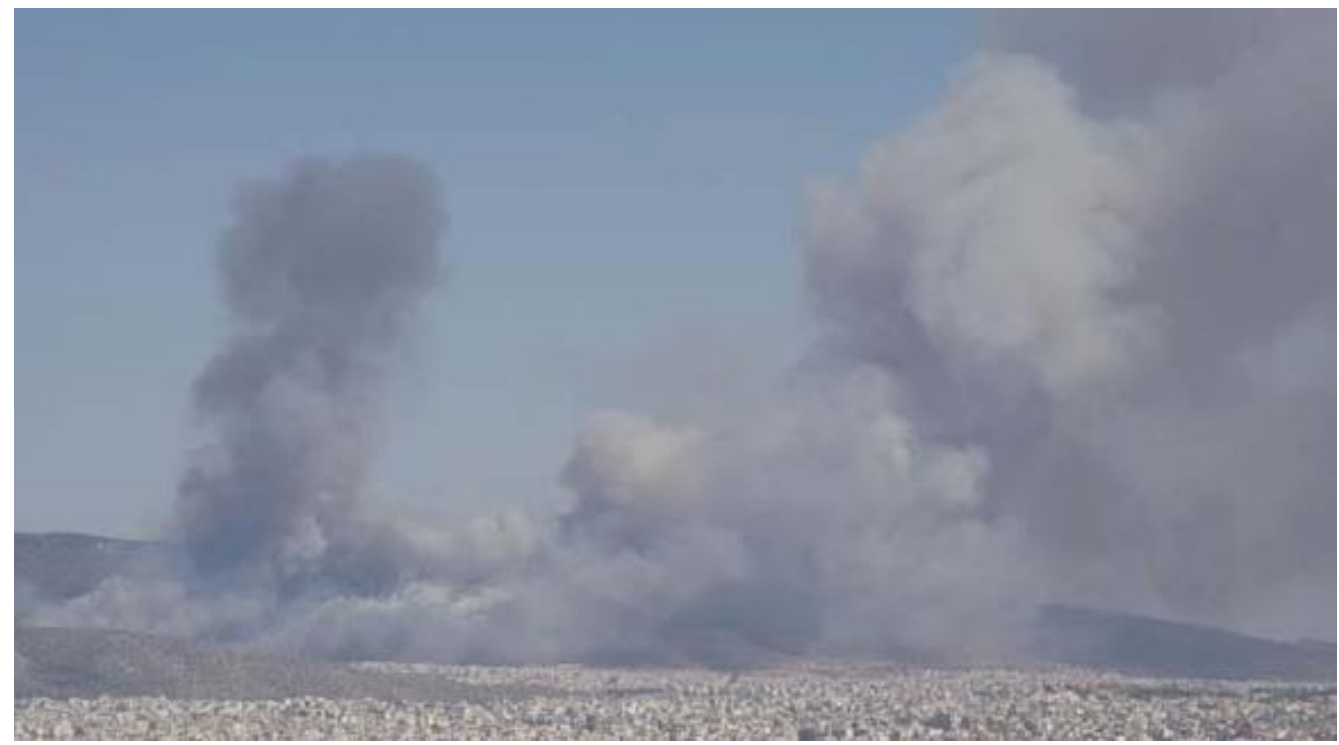

Figure 2 - An up-canyon run at the heel of a wind driven fire on Mount Hymettus, on June 15, 2009, that created a strong convection column separate from the column of the head of the fire (Source: amateur photo from www.athens.indymedia.org) 

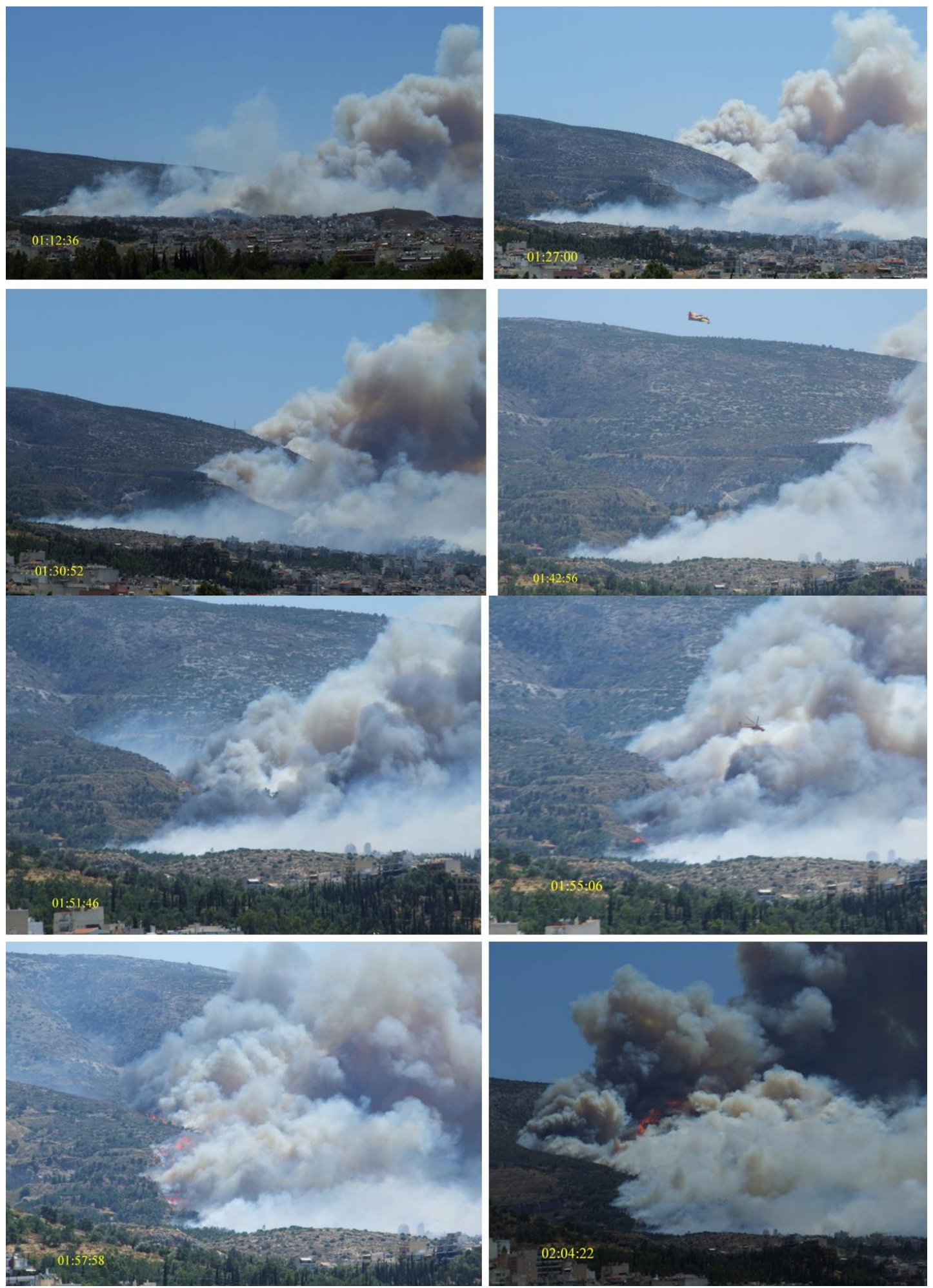

Figure 3 - The initial southwards spread of the Mount Hymettus fire of July 17, 2015, and the consecutive up-canyon runs that followed.

Especially the behaviour of the July 17, 2015 fire presented an excellent case study: the fire spread with the wind southwards and then succesively it backed-up four canyons. Recording the evolution of the fires as shown in Figure 3, and identifying the location of the fire with time, positioning it was possible to calculate the up-canyon rate of spread, in two runs, at $9 \mathrm{~km} / \mathrm{h}$ and $7.8 \mathrm{~km} / \mathrm{h}$. 


\section{Forest fire safety}

The spread within the canyons at a perpendicular direction to the prevailing wind has surprised many people and has been clearly the reason behind the deaths of three professional and one volunteer firefighters on the fire of Kareas, on July 22, 1998, in one of the canyons (Figures 4 and 5) (Xanthopoulos 2015). They stopped their fire truck at the bend of the road and tried to fight the fire that had started spreading up-canyon. They were immediately overwhelmed by the heat and the smoke and tried to run uphill in the canyon, entering a race that could not be won (Figure 6).

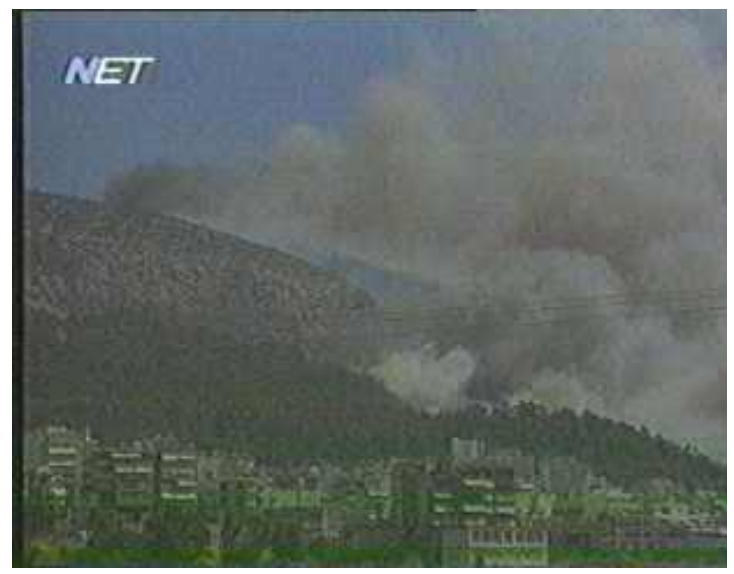

Figure 4 - The fire of Kareas of July 22, 1998, spreading within a canyon, perpendicular to the direction of the wind (Source: NET TV channel)

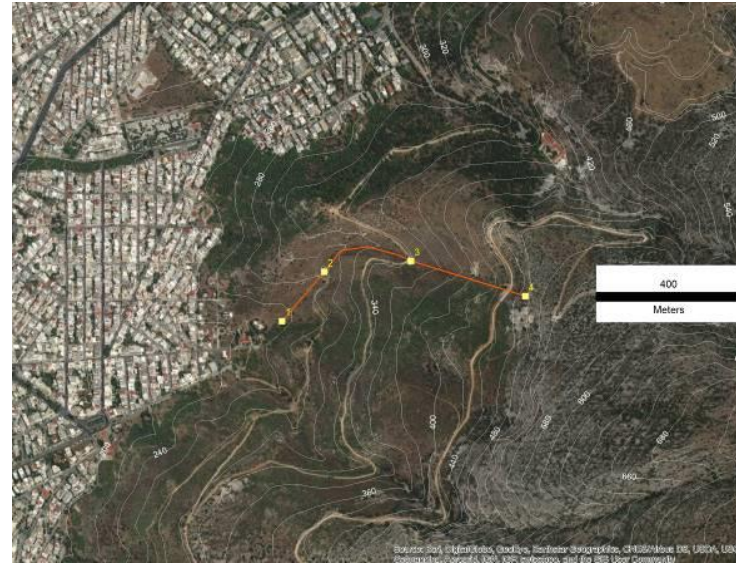

Figure 5 - The up-canyon spread of the fire of Kareas shown on a satelitte image from Google Earth. The main fire front advanced in a SW direction.

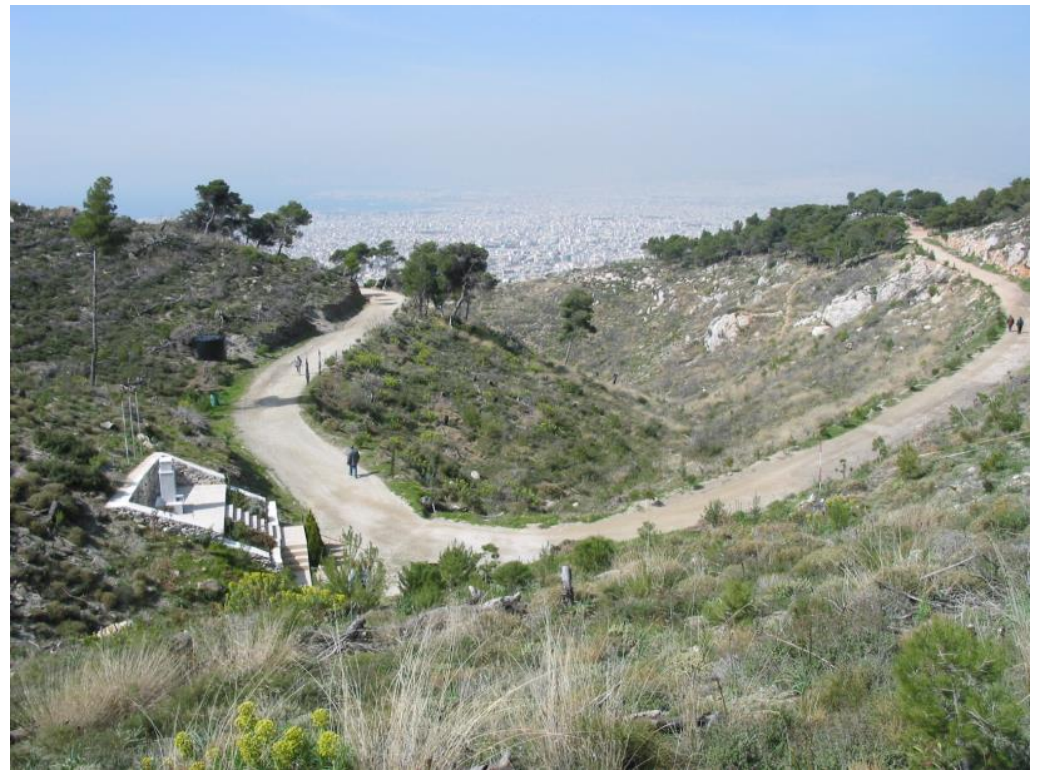

Figure 6 - The canyon within which the fire spread, photographed approximately from the locatin where the four firefighters died in 1998.

A few years later, on July 7, 2005, the same canyon burned again. This time it burned with a light up-canyon (SW) wind. In spite of reduced fuel load, the direction of the wind and the canyon topography resulted in a fire of significant intensity. Fortunately, this time the firefighters remained away from the axis of the canyon. Most of the suppression work was left to the aerial resources that included an Erickson S-64 helicopter and Canadair waterbombers (Figure 7). 


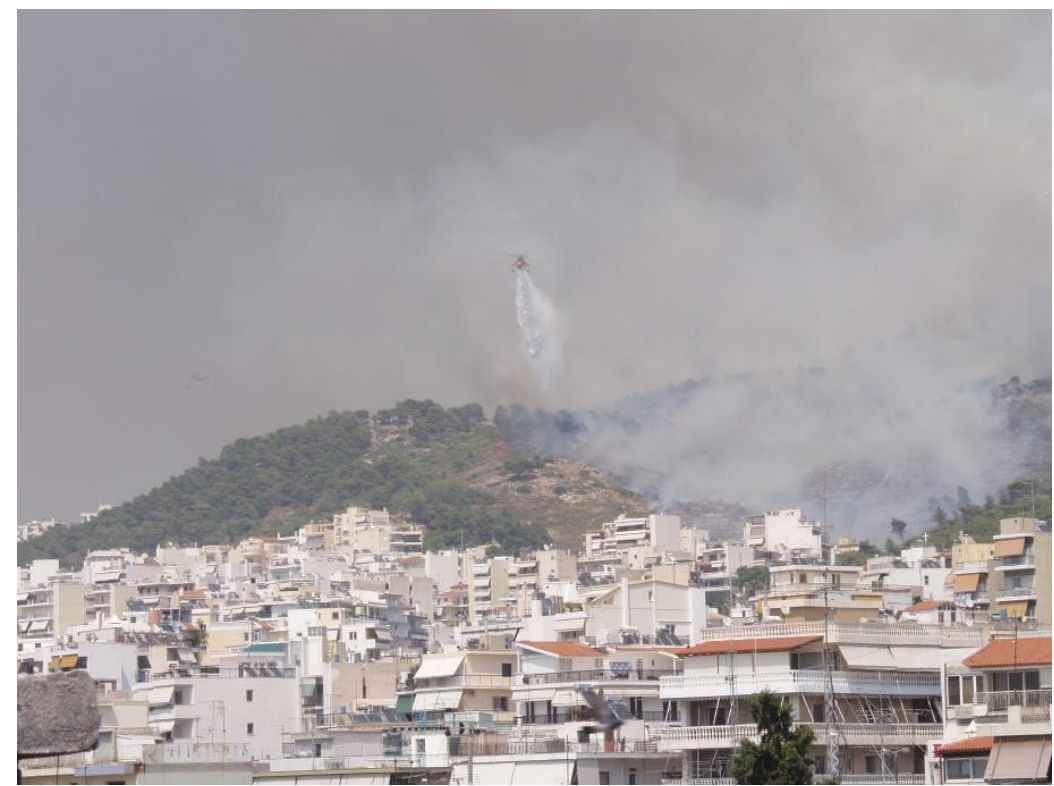

Figure 7 - Aerial firefighting during the up-canyon run of the Kareas fire on Hymettus mountain on July 7, 2005 (Photo: Foivos Theodorou, General Secretariat of Civil Protection, Greece)

The fire of July 17, 2015 also caused one fatality. This time it was a person jogging on the mountain, on a road with a north-south direction. The fire ignited and started burning below this road. The jogger called his family on his mobile to report about the fire saying that he was not worried. He was later found dead, about 100 meters higher than the road. It is likely that he was surprised by one of the upcanyon runs and tried unsuccessfully to escape to higher ground (Figure 8).

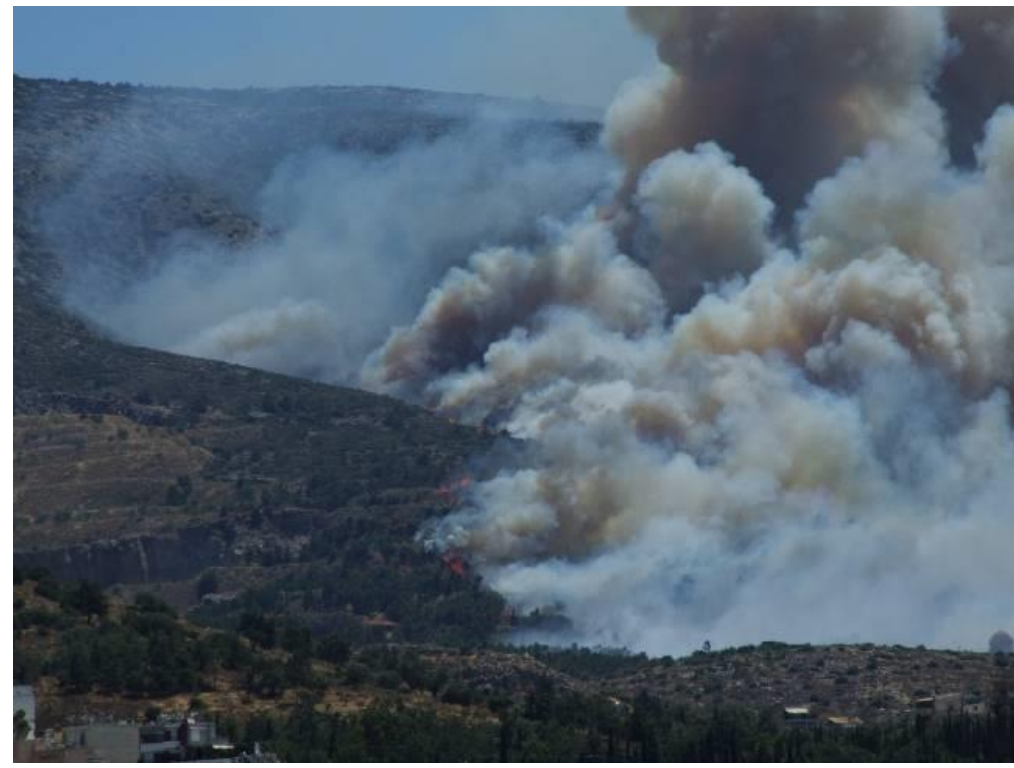

Figure 8 - The fire of July 17, 2015, on Mount Hymettus, which caused one fatality. The up-canyon fire spread in this particular canyon reached $9 \mathrm{~km} / \mathrm{h}$.

\section{Discussion and conclusions}

The fires of Mount Hymettus constitute a very good case study that encapsulates important fire prevention, behavior, firefighting and safety considerations. Regarding fire prevention the effectiveness of the measures taken for preventing fire starts, that include fire lookouts, ground patrols, and closed traffic bars on high fire danger days, can be judged as inadequate since a significant number of fires erupts every year. The response for initial attack by volunteers and professional firefighters 
with fire trucks is generally good so most of these fires remain small. However, the problem of traffic jams on the ring road at the western foothills of the mountain is clearly a central one as it results in delays in the arrival of heavier firetrucks from the city when initial attack fails. A potential measure in this direction is to condition the Athenian drivers, that often occupy the emergency lane in case of traffic jams, to refrain from such practice. This can be achieved, for example, through regular traffic police controls and special warning signs.

The fire behavior that has been observed and documented on Mount Hymettus, provides excellent material for studying, understanding and modelling the phenomenon of fire spread within "box canyons". As Viegas and Pita (2004) have shown, even in cases of quite shallow canyons a blow-up will always occur as long as space and time are available so that the fire to accelerate and create its own wind. This is related to the observation that the runs within the canyons of Mount Hymettus take place with some delay, after the general fire front has moved ahead in the direction of the wind (Figures 2 and 3$)$.

The eruptive fire behavior on Mount Hymettus must clearly be taken into consideration in firefighting plans. As stated by Viegas and Pita (2004), it is extremely dangerous to put resources at any place on the slope above the fire, especially in canyon topography, as the fire acceleration can occur at any time. This is even more important on the west-southwest facing slopes of Mount Hymettus which are mostly covered with shrub fuels, a situation that has been identified as of maximum danger by Page and Butler (2018) in a similar Mediterranean environment.

The knowledge presented here must clearly become part of the training of local firefighters, including the volunteers who have already faced a loss in 1998. Additionally, the death of the civilian in the 2015 fire shows that the public must be aware of the risk they may face in case of fires. The number of visitors on Mount Hymettus is quite large and a disastrous event including fatalities is not unlikely in case of extreme fire danger conditions. Forbidding visitor entrance to the mountain in case of such conditions, or at least providing information to those entering, may not only prevent fire starts but may also help avoid a potential disaster involving citizens.

\section{Acknowledgements}

The work presented here was carried out in the frame of the project MedWildFireLab ("Global Change Impacts on Wildland Fire Behaviour and Uses in Mediterranean Forest Ecosystems, towards a «wall less» Mediterranean Wildland Fire Laboratory") a European ERANet FORESTERRA project with funding from the General Direction for the Development and Protection of Forests and Agroenvironment of the Greek Ministry of Environment and Energy.

\section{Bibliography}

Page WG, Butler BW (2018) Fuel and topographic influences on wildland firefighter burnover fatalities in Southern California. International journal of wildland fire, 27(3), 141-154.

Sharples JJ, Gill AM, Dold JW (2010) The trench effect and eruptive wildifres: lessons from the King's Cross Underground disaster. In 'Proceedings of Australian Fire and Emergency Service Authorities Council 2010 Conference', 8-10 September 2010, Darwin, NT, Australia. (Australian Fire and Emergency Service Authorities Council: Darwin, NT, Australia) Available at http://www.maths.manchester.ac.uk/ jwd/articles/ 10-TEaEW.pdf [Verified 11 January 2018]

Viegas DX, Pita LP (2004) Fire spread in canyons. International Journal of Wildland Fire 13, 253 274.

Xanthopoulos G (2015) Wildfires and safety issues in Greece. In 'Current International Perspectives on Wildland Fires, Mankind and the Environment'. (Eds B Leblon, M Alexander) (Nova Science Publishers: Huntington, NY) 